\title{
A family study of hydrocephalus resulting from aqueduct stenosis
}

\author{
F M HOWARD, K TILL, AND C O CARTER \\ From the MRC Clinical Genetics Unit, Institute of Child Health, 30 Guilford Street, London \\ WCIN 1EH, and the Department of Neurosurgery, The Hospital for Sick Children, Great \\ Ormond Street, London WC1N $3 J H$
}

SUMMARY Stenosis of the aqueduct of Sylvius accounts for about one third of cases of congenital hydrocephalus. At least 32 families have been reported in which the aqueduct stenosis is inherited in an $\mathrm{X}$ linked fashion. In half of these families, flexed adducted thumbs were noted in some affected family members. Occasionally other male members were mentally retarded, suggesting limited expression of the gene. The problem of giving genetic advice to an isolated, clinically unremarkable, case of aqueduct stenosis remains, so a family study was undertaken based on 24 such cases seen at The Hospital for Sick Children over a 19-year period.

There were 15 male and nine female index patients. The diagnosis was confirmed in all cases by air encephalogram. One boy had a radial club hand and another developed clasped thumbs secondary to spasticity. No cases had hyaloidoretinal dysplasia. The 15 boys had 18 brothers and 19 sisters, of whom one sister was similarly affected. The nine girls had 12 sibs, none of whom was affected. This study, combined with a similar study in the USA, suggests that the empirical risk of recurrence of a sporadic case of aqueduct stenosis is about $4 \cdot 5 \%$.

Hydrocephalus has been recognised since antiquity (Paul of Aegina mentions it in the 7th century ${ }^{1}$ ) and occurs with an incidence of 0.5 to 1.8 per 1000 total births. ${ }^{2} 3$ About one third of congenital hydrocephalus is the result of stenosis of the aqueduct of Sylvius, ${ }^{4}$ although estimates vary from $11 \%$ to $43 \%^{6}$ Bickers and Adams in $1949^{7}$ and Edwards in $1961^{8}$ described aqueduct stenosis occurring in families and inherited in an $\mathrm{X}$ linked fashion. More than 32 families have since been recorded in published reports, and in 15 of these families some affected members had flexion adduction deformities of the thumbs. In addition, in some families, ${ }^{910}$ other male relatives on the maternal side have been mentally retarded, suggesting limited expression of the gene.

An editorial in the British Medical Journal in $1962^{11}$ estimated that something like $2 \%$ of all cases of uncomplicated hydrocephalus might be $\mathrm{X}$ linked. Genetic counselling is difficult in cases where the aqueduct stenosis is not marked by either adducted thumbs or by a characteristic $\mathrm{X}$ linked pedigree. We therefore decided to try and determine the proportion of isolated cases of aqueduct stenosis which is $X$ linked and to estimate empirical recurrence risks separately for each sex. During the course of this Received for publication 18 August 1980 study, the findings of a similar study from Chicago were reported by Burton. ${ }^{6}$

\section{Material and methods}

To determine the familial incidence of hydrocephalus associated with aqueduct stenosis, we took a consecutive series of all patients with aqueductal stenosis presenting to one of us (KT) in the neurosurgical unit over the 19-year period between February 1959 and February 1978. Fifty-three patients ( 31 males and 22 females) presented in this period. This is similar to the 59 cases presenting over the previous 19 years, who mostly did not undergo operation. ${ }^{12}$

After careful review of the history and investigations, including lateral skull $x$-rays, ventriculography, and lumbar air encephalogram, 23 (12 males and 11 females) were excluded, because the aqueduct stenosis was thought to be secondary to other intracranial lesions. These comprised meningitis and basal cisternal block ( 7 cases), pinealoma (2), birth trauma (2), intrauterine infection (2), non-accidental injury (2), neurofibromatosis (2), and one case each of encephalocele, arteriovenous malformation, maldevelopment of cerebellum, brain abscess, porencephaly, and Soto's syndrome. 
This left 30 cases. After getting the permission of the family doctors, family information was obtained by visiting the homes of 23 patients, and limited information was obtained by correspondence with one family. The families of six patients were not contacted. The reasons for this were living abroad (1), refused permission to visit (1), and not traced (all born before 1959) (4).

At the home visit, a pedigree was constructed and a pregnancy and perinatal history taken for the index patient and sibs. Any report of stillbirth, death, or survival with an abnormality in a sib was verified from medical records. Details of general health, handicap, and intelligence (from school reports) were obtained. Height, weight, and head circumference of parents and children were measured. The hands and feet were examined and the optic fundi examined by ophthalmoscopy.

\section{Results}

\section{CLINICAL DATA}

\section{Sex ratio}

There were 15 boys and nine girls. This is a nonsignificant male excess, but similar ratios have been found in previous series ascertained through neurosurgical clinics. 61314

\section{Birthweight}

No significant difference was found in the mean birthweights of the male and female index patients. Mean birthweight for boy patients was $3.46 \mathrm{~kg}$ (range $3.15 \mathrm{~kg}$ to $3.88 \mathrm{~kg}$ ), and for girls $3.37 \mathrm{~kg}$ (range $2.78 \mathrm{~kg}$ to $3.80 \mathrm{~kg}$ ). All babies were born at term, with the exception of one boy (No 5) who weighed $2.55 \mathrm{~kg}$ at 33 weeks' gestation and one girl (No 21) who weighed $1.02 \mathrm{~kg}$ at 28 weeks' gestation. Apart from their prematurity, these two index patients had no other perinatal problems, although their birthweights are excluded from the above figures.

\section{Age of diagnosis, operation, and progress}

The diagnosis was made and confirmed by air encephalogram at an average age of $2 \frac{1}{2}$ years (range birth to 10 years) for girls, and slightly later, $4 \frac{1}{2}$ (range birth to 10 years), for boys.

This is later than most other recorded series, although Harrison et al ${ }^{14}$ described 55 cases presenting postpubertally. Five boys (No 4, 6, 11, 18, 23) and three girls (No 2, 20,21) presented in the first 3 months of life. Four cases (No 10, 15, 18, 22) arrested spontaneously, and one (No 4) already had severe mental handicap at presentation. Torkildsen or ventriculoatrial shunts were performed at an average age of 6 years (range 2 weeks to 14 years) in the remaining probands. In seven of these cases the shunts were later revised.

The index patients were visited at an average age of 16 (range 3 to 27 years). Results from either type of shunt were broadly similar. Eleven of 19 patients were normal and six were educationally subnormal and had additional handicaps of strabismus and deafness. Two were severely subnormal, and one of these (No 1) died. These results are very similar to those obtained from the Midlands Centre. ${ }^{13}$

\section{Physical examination}

The optic fundi were examined by ophthalmoscopy in 21 cases. Two patients were dead, and information was obtained by letter in a third. In no case were hyaloidoretinal dysplasia or retinal folds observed. ${ }^{15}$ Hands and feet were examined in 21 index patients, their sibs, and parents. One boy (No 8) had a left radial club hand with an absent radius, first metacarpal, and thumb. His right hand was normal. One index patient (No 4), the blind, severely subnormal, spastic quadriplegic boy who died, unoperated, aged 16 , was said to have clasped thumbs from the age of 3. However, at this stage he had marked contractures of the limbs, so it seems reasonable to suppose that his adducted thumbs were secondary to his spasticity.

One boy (No 12) had had an ectopic anus dilated at birth and there were no other congenital malformations.

\section{Search for environmental factors}

No significent trends were observed after analysis for birth order, maternal age (average 25.5 years), season of birth and conception, or socioeconomic class. No consistent history of drug ingestion was obtained, although specific enquiries were made about aspirin ${ }^{16}$ and barbiturate ${ }^{17}$ ingestion. No history of viral illness, mumps, ${ }^{18}$ or influenza ${ }^{19}$ was obtained.

\section{FAMILY DATA}

Parental consanguinity

One female index patient (No 16) had first-cousin English parents. She had a normal elder brother. Her symptoms started with ataxia at age 11. Her thumbs and fundi were normal and a successful Torkildsen shunt was performed.

\section{Twins}

No twins were recorded among the index patients. One mother (of No 22) may have miscarried a twin sib at the fourth month of pregnancy.

Sibs

The proportion of affected sibs of probands is 
TABLE Proportion of affected sibs of probands (Weinberg proband method)

\begin{tabular}{|c|c|c|c|c|c|c|}
\hline \multicolumn{2}{|c|}{ Index case } & \multicolumn{2}{|c|}{ Brothers } & \multicolumn{2}{|c|}{ Sisters } & \multirow{2}{*}{$\begin{array}{l}\text { Total } \\
\text { affected }\end{array}$} \\
\hline & & Before & After & Before & After & \\
\hline $\begin{array}{l}\mathbf{M} \\
\mathbf{F} \\
\text { Total }\end{array}$ & $\begin{array}{r}15 \\
9 \\
24\end{array}$ & $\begin{array}{l}0 / 8 \\
0 / 3\end{array}$ & $\begin{array}{l}0 / 10 \\
0 / 1\end{array}$ & $\begin{array}{l}1 / 9 \\
0 / 3\end{array}$ & $\begin{array}{l}0 / 11 \\
0 / 5\end{array}$ & $\begin{array}{l}1 / 38 \\
0 / 12 \\
1 / 50\end{array}$ \\
\hline
\end{tabular}

summarised in the table, using the Weinberg proband method by which the sibship is entered once for each independently ascertained patient in the initial sample.

Only one affected sib was found out of 50. This was the elder sister of No 23 , the third child of unrelated Irish parents. He was born by normal delivery at 39 weeks' gestation, birthweight $3.57 \mathrm{~kg}$, the head circumference at birth of $36.5 \mathrm{~cm}$ rising to $39 \mathrm{~cm}$ by one week of age. Air encephalogram confirmed aqueduct stenosis with no basal cisternal block. A ventriculoatrial shunt was performed at 2 weeks and had to be revised several times. $\mathrm{He}$ is now severely subnormal with a right hemiplegia. His thumbs are normal. His elder sister was born at term, weighing $3.40 \mathrm{~kg}$, and presented at 8 months with increasing head circumference (now $54 \mathrm{~cm}$ ). Air encephalogram revealed aqueduct stenosis with no basal cisternal block or anomaly at the foramen magnum. Ventriculoatrial shunting was successfully performed, and she is now, at 14, of dull normal intelligence. She has a squint but no other neurological abnormality, and her thumbs are normal. There are three other normal sisters. There is no history of hydrocephalus, stillbirth, or mental retardation among first and second degree relatives.

There were no other affected sibs, either hydrocephalic or mentally retarded. Two sibs (of No 5 and 11) had died of congenital heart disease.

\section{Cousins}

There were 87 maternal first cousins and 92 paternal first cousins of the 14 male index patients. On enquiry, none was hydrocephalic or mentally retarded. Female index patients had 17 maternal first cousins and 12 paternal first cousins, none of whom was affected. There was very little family pathology and only two stillbirths (one a twin, the other a Potter anomalad) and one paternal and one maternal cousin had spina bifida and hydrocephalus. One maternal second cousin (of No 5), a boy, died at 14 with hydrocephalus, an absent eye, and left hemiplegia.

\section{Discussion}

In this series of hydrocephalus resulting from aqueduct stenosis there was a non-significant excess of males, but no other evidence of $\mathrm{X}$ linked inheritance. $\stackrel{\overrightarrow{\mathbb{Q}}}{?}$ On examination, no case had the congenital ad- $\vec{\Rightarrow}$ ducted flexed thumbs first described by Edwards. ${ }^{20} \stackrel{\text { 足 }}{\rightarrow}$ The proportion of brothers affected of male index patients was $0 / 18$. There is one other comparable $\frac{\bar{G}}{\bar{N}}$ series, by Burton from Chicago, ${ }^{6}$ which was pub- $\frac{\text { D }}{\vec{D}}$ lished after we began this study. She reported $88 \AA$ cases with aqueductal obstruction (57 males, 31 \% females). None of the patients had adducted thumbs, $\vec{\circ}$ although one sporadic case had absent thumbs. Three male patients had mother's brothers and one a $\vec{\omega}$ mother's sister's son affected. Excluding these clearly $\mathrm{X}$ linked cases, $2 / 29$ brothers and $0 / 27$ sisters of male patients were affected. Combining this series with our own, the proportion affected of brothers of a male patient is therefore $2 / 47$ or $1 / 23$, and of their sisters $1 / 47$. The proportion affected of sibs of N female index patients is $0 / 32$ brothers and $0 / 39$ sisters. 음

Our affected brother (No 23) and sister pair are compatible with either autosomal recessive or multifactorial inheritance. There are only two similar cै published reports. Mehne ${ }^{21}$ described three sibs, two $\stackrel{\leftarrow}{\stackrel{C}{\leftrightarrow}}$ male and one female, all dying within 5 months of $\overrightarrow{\vec{\theta}}$ birth. Their thumbs were normal and two (one male, $₫$ one female) were shown to have aqueduct stenosis. Warkany ${ }^{22}$ described a sibship of 13 (eight males, five females) with first cousin parents. Nine children were normal and four (three males, one female) were hydrocephalic. Necropsy of one affected boy showed aqueduct stenosis, microgyria, and cerebellar and medullary hypoplasia. The five stillborn female sibs reported by Fowler et $\mathrm{l}^{23}$ had gross hydrocephalus, contractures, and gliosis, a different condition, as is recessive hyaloidoretinal dysplasia and aqueduct stenosis. ${ }^{15}$

\section{Genetic counselling}

This series, combined with that of Burton, ${ }^{6}$ may be used to provide an estimate of the recurrence risk after parents have had a child surviving with aqueduct stenosis, where there is no family history indicating $X$ linkage. The estimate is $4.5 \%$ for the brother and $2 \%$ for the sister of a male patient and probably $1 \%$ or less for the sibs of female $N$ patients. However, in the reported families with $\mathrm{X} N$ linked hydrocephalus, ${ }^{367924-29}$ half $(42 / 84)$ of $\mathcal{N}$ the affected males have been stillborn or neonatal $\omega$ deaths. Estimates based on surviving patients coming to operation may not therefore apply where the patient died perinatally.

We would like to thank Dr W Jerry Oakes, (neurological surgeon, Duke University Medical Center, North Carolina, USA) for an expert review of all the air encephalograms. 


\section{References}

1 Aegina Paulus. Lib VI 3. Quoted by GS Still. History of paediatrics. London: Oxford University Press, 1931.

2 Carter CO, David PA, Laurence KM. A family study of major CNS malformations in South Wales. J Med Genet $1968 ; 5: 81-107$.

3 Shannon MW, Nadler HL. X-linked hydrocephalus. J Med Genet 1968;5:326-9.

4 Elvidge AR. Treatment of obstructive lesions of the aqueduct of Sylvius and the fourth ventricle by interventriculostomy. J Neurosurg 1966;24:11-23.

5 Gilly R, Cotton J, Farouz S, Nairet A, Maclet M. Hydrocéphalie congénitale et anomalie bilatérale des pouces. Pediatrie $1971 ; 26: 365-77$.

6 Burton BK. Recurrence risks for congenital hydrocephalus. Clin Genet 1979;16:47-53.

7 Bickers DS, Adams RD. Hereditary stenosis of aqueduct of Sylvius as cause of congenital hydrocephalus. Brain $1949 ; 72: 246-62$.

8 Edwards JH, Norman RM, Roberts JM. Sex-linked hydrocephalus. Report of a family with 15 affected members. Arch Dis Child 1961;36:481-5.

9 Fried K. X-linked mental retardation and/or hydrocephalus. Clin Genet 1972;3:258-63.

10 Aicardi J, Briard ML, Chevrie JJ. A genetic study of hydrocephalus. European child neurology society meeting. Abst. 1979.

11 Editorial. Sex-linked hydrocephalus with severe mental defect. Br Med J 1962;i:168.

12 Laurence KM. Natural history of hydrocephalus. Arch Dis Child 1962;37:345-62.

13 McMillan JJ, Williams B. Aqueduct stenosis. Case review and discussion. J Neurol Neurosurg Psychiatry 1977;40:521-32.

14 Harrison MJG, Robert CM, Uttley D. Benign aqueduct stenosis in adults. J Neurol Neurosurg Psychiatry 1974; 37:1322-8.

15 Warburg M. Hydrocephaly, congenital retinal non-attachment and congenital falciform fold. Am J Ophthalmol $1978 ; 85: 88-94$.

16 Adeloye A, Warkany J. Experimental congenital hydrocephalus. Childs Brain 1976;2:325-60.
17 Jezequel C, Belloir D, Jehan P, Ramée $\mathbf{M}$, Coutel $\mathbf{Y}^{\cdot}$ Hydrocéphalie congénitale, anomalie bilatérale des pouces et malformations oculaires. Ann Pediatr 1973; 20:927-34.

18 Johnson RT, Johnson KP. Hydrocephalus following viral infections: the pathology of aqueduct stenosis developing after experimental mumps virus infections. $J$ Neuropathol Exp Neurol 1968;27:591-606.

19 Krous HF, Altshuler G, London WT, Palme AE, Fucillor DA, Sever JL. Animal model of human disease: congenital hydrocephalus. Am J Pathol 1978;92:317-20.

20 Edwards JH. The syndrome of sex-linked hydrocephalus. Arch Dis Child 1961;36:486-93.

21 Mehne RG. Three hydrocephalic newborn. Arch Pediatr $1961 ; 78: 67-71$.

22 Warkany J. Congenital malformations. Chicago: Year Book Medical Publishers, 1971 : 217-29.

23 Fowler MR, Dow R, White TA, Greer CH. Congenital hydrocephalus-hydrocephaly in 5 siblings with autopsy studies. A new disease. Dev Med Child Neurol 1972;14: 173-88.

24 Needleman HL, Root AW. X-linked hydrocephalus. Pediatrics 1963;31:396-9.

25 Cassie R, Boon AR. Sex-linked hydrocephalus. J Med Genet 1977;14:72-3.

26 Fandre M, Leroux B, Couchot J, Pennaforte F, Pluot B. Hydrocéphalie liée au sexe. A propos de trois familles distincte. Arch Fr Pediatr 1972;29:778 (abst).

27 Martin CI, Got M, Babin JP, Cazavran JM. Hydrocéphalie familiale, maladie hereditaire recessive gonosomique. Arch Fr Pediatr 1971;28:971-4.

${ }^{28}$ Price JR, Horne BM. Family history indicating hereditary factors in hydrocephalus. Ment Retard $1968 ; 6: 40$.

29 Søvik O, Birger van der Hagen C, Løken AC. X-linked aqueduct stenosis. Clin Genet 1977;11:416-20.

Requests for reprints to Professor C O Carter, MRC Clinical Genetics Unit, Institute of Child Health, 30 Guilford Street, London WC1N 1EH. 